\title{
Examining the Attitudes of Candidate Social Studies Teachers' Regarding the Contemporary World Problems ${ }^{1}$
}

DOI: $10.26466 /$ opus. 952872

\author{
$*$ \\ Ünal Șimşek* \\ * Asst. Prof. Dr. Aksaray University, Faculty of Education, Aksaray/Turkey \\ E-Mail: unalsimsek63@gmail.com \\ ORCID: 0000-0002-9102-0095
}

\begin{abstract}
The world faces problems originating from environmental pollution, air pollution, unbalanced population growth, unemployment, climate changes, differences in vegetation, water problems, drought, disasters, wars, nuclear wars and weapons, unplanned urbanization, genocide, hunger, terrorism, energy, refugees, poverty, racism, technology, media, economy, communication, health, education, agriculture, women's problems, problems originating from belief and sect. This research aims to determine the attitudes of social studies candidate teachers' regarding contemporary world problems. The present study is quantitative research and it was figured in survey model. The survey model is a research approach that aims to reveal a situation that existed in the past in its current form. The study group of the research was composed of 167 candidate teachers' who continue their studies at Aksaray University, Faculty of Education, Department of Social Studies Education. Convenient sampling, which is one of the sampling types of the research, was used. The data in the research were collected through the "Attitude Scale Intended for Contemporary World Issues" developed by Kıllı̧oğlu, Karakuş and Öztürk (2012). Looking at the results of the research, it was concluded that there was no significant difference between the total scores of the participants' attitudes towards contemporary world problems and the variable of gender, class variable, following daily newspaper news in printed and electronic media, being a member of an $N G O$, and father's education level. It was concluded that there was a significant difference only between the education level of the mother.
\end{abstract}

Key Words: Candidate social studies teachers', today's world problems, attitude.

\footnotetext{
${ }^{1}$ This research, "International Symposium of Education and Values - 4" presented as a notification.
} 


\section{Sosyal Bilgiler Öğretmen Adaylarının Günümüz Dünya Sorunlarına İlişkin Tutumlarının İncelenmesi}

*

Öz

Dünya, çevre kirliliği, hava kirlilĭği, dengesiz nüfus artışı, işsizlik, iklim değişiklikleri, bitki örtüsünde yaşanan farklılık, su sorunlarl, kuraklık, afetler, savaşlar, nükleer savaşlar, nükleer silahlar, çarpık kentleşme, soykırım, açlık, terör, enerji, mülteci, yoksulluk, ırkçılık, teknoloji, medya, ekonomi, iletişim, săğlk, eğitim, tarım, kadınların sorunları, inanç ve mezhep kaynaklı sorunlarla karşı karşıyadır. Bu araştırmanın amact, sosyal bilgiler öğretmen adaylarının günümüz dünya sorunlarına ilişkin tutumların tespit etmektir. Bu çalışma nicel araştırma olup tarama modeliyle desenlenmiştir. Tarama modeli, geçmişte var olan bir durumu mevcut haliyle, ortaya koymayı amaçlayan araştırma yaklaşımıdır. Araştırmanın çalışma grubunu Aksaray Üniversitesi, Eğitim Fakültesi, Sosyal Bilgiler Öğretmenliği bölümünde öğrenimlerini gören 167 öğretmen adayı oluşturmaktadır. Araştırmanın örnekleme türlerinden olan uygun örnekleme kullanılmıştır. Araştırmada veriler, Kılıçoğlu, Karakuş ve Öztürk (2012) tarafindan geliştirilen "Günümüz Dünya Sorunlar Tutum Ölçeği" aracıllğılyla toplanmıştır. Araştırmanın sonuçlarına bakıldı̆̆ında, katılımcıların günümüz dünya sorunlarına ilişkin tutum toplam puanlarn ile cinsiyet değişkeni, sınıf değişkeni, basılı ve elektronik ortamda günlük gazete haberlerini takip etme değişkeni, bir STK'ya üye olma değişkeni, baba eğitim düzeyi değişkeni arasında anlamlı bir farklılı̆̆ın olmadığı sonucuna ulaşılmıştır. Yalnızca anne eğitim düzeyi arasında ise anlamlı farklılı̆̆ın olduğu sonucuna ulaşılmıştır.

Anahtar Kelimeler: Sosyal bilgiler öğretmen adayları, günümüz dünya sorunları, tutum. 


\section{Introduction}

Problems and conflicts in the global world have a significant impact on human life. It is seen that these problems increase in size with each year. As a matter of fact, in the 21st century, the world faces environmental pollution, air pollution, unbalanced population growth, unemployment, climate changes, differences in vegetation, water problems, drought, disasters, wars, nuclear wars and weapons, unplanned urbanization, genocide, hunger, terrorism, energy, refugees, poverty, racism, technology, media, economy, communication, health, education, agriculture, women's problems, problems originating from belief and sect (Demirkaya, 2016; Harris, 2004; Kılıçoğlu, Karakuş and Öztürk, 2012; Özgen, 2012; Tapan, 2006; Yazıc1, 2013; Yazıcı and Arıbaş, 2011). As a matter of fact, what these problems have in common is that they affect the whole world and humanity. However, it is seen from the fact that the existing problems continue to increase that the national/international activities for the solution of the problem are not sufficient. Based on the contemporary world problems, lie excessive tension, instability, unpredictability and lack of planning. Interdependence and all global problems are interconnected, no matter what form we divide them into any group. It has been already said that they have common reasons (lagging behind in solutions and correction mechanisms of the asymmetrical forms of interdependence and mastering of the accelerated manifestations of the economic life and the common activities in general internationalisation), but they can also have common and mutually conditioned consequences. Basically, all global issues are interconnected, albeit only indirectly in some cases (Jeníček, 2008, p.66).

With the social, political and economic problems in the world reaching to peak by affecting people, the necessity for states to communicate at a global level has become mandatory. Countries felt the need to find common solutions to overcome these global crises. At this point, the World Economic Forum, which is held every year to find solutions to problems by revealing the global trends and risks in the world, with participants representing 134 countries, gathers. In this forum, it is stated that there is actually a fragmented world and there is an effort to create a future from it. It is stated that this situation points to a big problem such as the concept 
of "separation" in the global world that is the separation of countries and societies from each other (Ivanov, 2018; World Economic Forum, 2018). State that any of the global problems can endanger the entire human civilization if it develops on its own in an uncontrolled manner. In a relatively short time, other global problems related to both human interaction and their relationship with nature with the worsening of related and consequential problems, truly catastrophe may be inevitable (Robertson, 1992). There is a need for social awareness and education to prevent them.

Despite these negativities on a global scale, countries must seek solutions to existing problems to leave a peaceful, happy and livable world to future generations. In addition, awareness studies should be carried out on the problems to raise individuals' social awareness (Tapan, 2006). It is crucial to inform students about the significance and effects of these problems in the world, to raise their awareness, and to encourage them to actively participate in the solution of these problems. For this reason, the education and training process plays a key role in making students aware of the contemporary social problems that our world is facing and that concern the majority of the society, and to raise them as conscious individuals in the face of problems (Bell, 2004; Uymaz, 2021). Within the framework of the pieces of training to be implemented, firstly the existing problems will be introduced and recognized, then the individuals who make up the society and all the stakeholders involved in the decision-making processes in the society will gain a healthier, conscious and solution-oriented perspective on the subject. (Baylan, 2009; Kan, 2012; Özey, 2001; Yavaş, 2011). The important point here is to prepare the right educational content and to create a quality educator profile. After the pieces of training, seminars and lectures to be given in this way, individuals' awareness of the problems that exist in the world can increase and individuals can take a stance and gain skills on the subject.

It is extremely important to raise awareness of the students about the significance and effects of problems that concern the masses, to inform them and to encourage them to be a part of the solution. For this, it is beneficial to first determine what kind of an attitude the candidate teachers' have towards world problems. In the social studies undergraduate curriculum, which dwells on the problems in the world, and aims to raise awareness in this sense, there is a course in the field's elective category called 
"Contemporary World Problems". At this point, it is a requirement of the social studies course, which has a mission to educate sensitive and responsible citizens, and for the candidate teachers' of social studies, who study at the university to become teachers of this country, to recognise the problems that exist in contemporary world and to show responsibility in finding solutions to these problems. The findings of this study will contribute to researchers, teachers, candidate teachers' and students at all levels who examine contemporary world problems. From this point of view, the aim of the research is to determine the attitudes of social studies teacher candidates towards contemporary world problems.

Sub-problems Related to the Research;

- Is there a significant relationship between the attitudes of social studies candidate teachers' towards contemporary world problems and their gender?

- Is there a significant relationship between the attitudes of social studies candidate teachers' towards contemporary world problems and their class level?

- Is there a significant relationship between the attitudes of social studies candidate teachers' towards contemporary world problems and their status of following daily newspaper news in printed and electronic media?

- Is there a significant relationship between the attitudes of social studies candidate teachers' towards contemporary world problems and their status of being a member of an NGO?

- Is there a significant relationship between the attitudes of social studies candidate teachers' towards contemporary world issue and their mother's education level?

- Is there a significant relationship between the attitudes of social studies candidate teachers' towards contemporary world problems and their father's education level?

\section{Method}

This study is quantitative research and it was figured in a survey model. The survey model is a research approach that aims to explain and describe an existing situation as it is. In this model, there is no intervention, change 
or influence on the problem that is the subject of the research. In other words, it is crucial to observe and describe the situation as the way it is (Karasar, 2010). In addition, the survey model is defined as a type of research that is frequently used because it reveals an existing situation as the way it exists, allows working on large samples and gives researchers ideas about the opinions of the participants on a subject or a certain event (Büyüköztürk, Kılıç-Çakmak, Akgün, Karadeniz and Demirel, 2010).

Study Group: The study group of the research consists of students of Aksaray University, Faculty of Education, Department of Social Studies Education in the 2020-2021 academic year. In the research, an attitude scale towards contemporary world problems was applied to 167 candidate teachers' in the Department of Social Studies Teaching. Convenience sampling, one of the non-random sampling types, was used in the sampling of the study.

Data Collection Tool: In this research, the data were collected through the "Attitude Scale Intended for Contemporary World Issues" developed by Kılıçoğlu, Karakuş and Öztürk (2012). The "Personal Information Form" was given to candidate teachers' along with the "Attitude Scale Intended for Contemporary World Issues".

Analysis of Data: The data obtained in the study were analysed in accordance with the data collection techniques used. The data were analysed using the SPSS 21.0 (Statistical Package for Social Sciences) program. Different analysis techniques were used to determine the relationship between the variables of the study and the total scores obtained from the attitude scale intended for contemporary world issues.

\section{Findings}

In this section, the analysis results revealing the relationships between the variables and the total scores obtained from the Attitude Scale Intended for Contemporary World Issues of the candidate teachers' participating in the study are shown. 
Table 1. T-test results of participants' attitudes to contemporary world problems according to the gender variable

\begin{tabular}{lllllll}
\hline Gender & $\mathbf{N}$ & $\overline{\mathbf{X}}$ & $\mathbf{S}$ & $\mathbf{s d}$ & $\mathbf{t}$ & $\mathbf{p}$ \\
\hline Female & 111 & 104,1712 & 10,90194 & \multirow{2}{*}{,} & \multirow{2}{*}{367} & \multirow{2}{*}{, 714} \\
Male & 56 & 104,7857 & 8,67329 & & & \\
\hline
\end{tabular}

According to Table 1, there is no significant difference between participants' total scores of the attitude toward contemporary world problems and the gender variable $\left[t_{(165)}=, 367 ; p>, 05\right]$. While the average of women's scores of the attitude toward contemporary world problems is ( $\overline{\mathrm{X}}$ $=104,17)$, the average of men's scores of the attitude toward contemporary world problems is ( $\bar{x}=104,79)$. The difference is not statistically significant. This finding can be interpreted as that the gender of the participants does not cause any differentiation in their attitude towards contemporary world problems.

Table 2. One-way variance analysis (ANOVA) results for the difference of participants' attitudes towards contemporary world problems according to the undergraduate year variable



According to Table 2, there is no significant difference between the participants' total scores in attitudes for contemporary world problems and the year variable $\left[\mathrm{F}_{(3-163)}=2,437 ; \mathrm{p}>, 05\right]$. this finding can be interpreted as that the undergraduate year levels of the participants in which they study do not cause any difference in their attitudes towards contemporary world problems. 
Table 3. The t-test results of the participants' attitudes towards contemporary world problems according to the variable of following daily newspaper news in print and electronic media

\begin{tabular}{lllllll}
\hline $\begin{array}{l}\text { Following Daily Newspa- } \\
\text { pers in Print and Electronic N } \\
\text { Environment }\end{array}$ & $\bar{X}$ & $\mathbf{S}$ & sd & $\mathbf{t}$ & $\mathbf{p}$ \\
\hline Yes & 113 & 104,8673 & 10,18271 & 165 &, 899 &, 370 \\
No & 54 & 103,3519 & 10,21312 & & & \\
\hline
\end{tabular}

According to Table 3, there is no significant difference between participants' total scores from the attitude towards contemporary world problems and the variable of following daily newspaper news in printed and electronic media [ $\left.\mathrm{t}_{(165)}=, 899 ; \mathrm{p}>, 05\right]$. While the attitude score average regarding contemporary world problems of those who follow newspaper news daily in print and electronic media is ( $\overline{\mathrm{x}}=104,87$ ), the attitude score average regarding contemporary world problems of those who do not follow is $(\bar{x}=103,35)$. The difference is not statistically significant. This finding can be interpreted as that participants' status of following newspaper news in print or electronic media does not differentiate their attitudes towards contemporary world problems.

Table 4. T-test results of the participants' attitudes towards contemporary world problems according to the variable of the participants' status of being a member of $\mathrm{NGOs}$

\begin{tabular}{lllllll}
\hline $\begin{array}{l}\text { The Status of Being a Mem- } \\
\text { ber of an NGO }\end{array}$ & $\overline{\mathbf{X}}$ & $\mathbf{S}$ & sd & $\mathbf{t}$ & $\mathbf{p}$ \\
\hline Yes & 22 & 106,2273 & 9,74402 & 165 &, 914 &, 362 \\
No & 145 & 104,0966 & 10,25530 & & & \\
\hline
\end{tabular}

According to Table 4, there is no significant difference between the total attitude scores of participants regarding contemporary world problems and the variable of being a member of NGOs $\left[t_{(165)}=, 914 ; p>, 05\right]$. The score average of the attitude toward contemporary world problems of those who are a member of NGOs is $(\bar{x}=106,23)$ while the score average of the attitude toward contemporary world problems of those who are not members of NGOs are $(\bar{x}=104,10)$. The difference is not statistically significant. This finding can be interpreted as that the participation of participants in 
non-governmental organisations do not cause them to differentiate in their attitudes towards contemporary world problems.

Table 5. One-way variance analysis (ANOVA) results for the difference of participants' attitudes towards contemporary world problems according to their mother's education level variable

\begin{tabular}{|c|c|c|c|c|c|c|c|}
\hline Variable & \multirow{2}{*}{\multicolumn{2}{|c|}{ (1)Illiterate }} & $\mathbf{N}$ & \multicolumn{2}{|l|}{$\bar{X}$} & \multicolumn{2}{|r|}{$S$} \\
\hline \multirow{9}{*}{$\begin{array}{l}\text { Mother's } \\
\text { Educa- } \\
\text { tion } \\
\text { Level }\end{array}$} & & & 20 & 108 & & & 498 \\
\hline & (2)Primary Schoo & & 93 & 105 & & & 0904 \\
\hline & (3)Middle Schoo & & 27 & 106 & & & 289 \\
\hline & (4)High School & & 18 & 97, & & & 2350 \\
\hline & (5)University & & 9 & 95 & & & 1325 \\
\hline & Varience Source & KT & $\mathrm{Sd}$ & $\mathrm{KO}$ & $\mathrm{F}$ & $\mathrm{p}$ & $\begin{array}{l}\text { Differ- } \\
\text { ence } \\
\text { Scheffe } \\
\end{array}$ \\
\hline & Intergroups & 2133,338 & 4 & 533,335 & 5,725 & ,000 & \\
\hline & In Groups & 15091,895 & 162 & 93,160 & & & $\begin{array}{l}1-4 \\
1-5\end{array}$ \\
\hline & Total & 17225,234 & 166 & & & & \\
\hline
\end{tabular}

According to Table 5, there is a significant difference between the total attitude scores of participants regarding contemporary world problems and the variable of participants' mother's education level $\left[\mathrm{F}_{(4-162)}=5,725\right.$; $\mathrm{p}<$,05]. Scheffe multi-comparison test was conducted to find out which groups this difference is among. The results showed that among the total point average attitude scores regarding the contemporary world problems of those whose mother is illiterate $(\bar{X}=108,80)$ and whose mother's education level is high school $\left(\bar{X}_{=97,33)}\right.$ and university $\left(\bar{X}_{=95,56) \text { a difference }}\right.$ in favour of those whose mother is not literate was found. This finding can be interpreted as attitudes of those with illiterate mothers towards contemporary world problems are fairly more positive.

According to Table 6, there is no significant difference between the total attitude scores of participants regarding contemporary world problems and the variable of participants' father's education level $\left[F_{(4-162)}=1,566\right.$; $\mathrm{p}>, 05]$. This finding can be interpreted as participants' father's education level do no cause differentiation in their attitude towards contemporary world problems. 
Table 6. One-way variance analysis (ANOVA) results for the difference of participants' attitudes towards contemporary world problems according to their father's education level variable

\begin{tabular}{|c|c|c|c|c|c|c|c|}
\hline $\begin{array}{l}\text { Varia- } \\
\text { ble }\end{array}$ & & \multicolumn{2}{|c|}{$\mathbf{N}$} & \multicolumn{2}{|l|}{$\overline{\mathrm{X}}$} & \multicolumn{2}{|r|}{$S$} \\
\hline \multirow{9}{*}{$\begin{array}{l}\text { Fa- } \\
\text { ther's } \\
\text { Edu- } \\
\text { cation } \\
\text { Level }\end{array}$} & (1)Illiterate & & & & 3000 & & 6,30079 \\
\hline & (2)Primary School & & & & 9984 & & 11,60417 \\
\hline & (3)Middle School & & & & 609 & & 8,82467 \\
\hline & (4)High School & & & & 121 & & 9,56804 \\
\hline & (5) University & & & & 273 & & 9,54155 \\
\hline & Source Varience & KT & $\mathrm{Sd}$ & $\mathrm{KO}$ & $\mathrm{F}$ & $\mathrm{p}$ & $\begin{array}{l}\text { Differ- } \\
\text { ence } \\
\text { Scheffe }\end{array}$ \\
\hline & Intergroups & 641,275 & 4 & 160,319 & 1,566 & 186 & \\
\hline & In Groups & 16583,958 & 162 & 102,370 & & & \\
\hline & Total & 17225,234 & 166 & & & & \\
\hline
\end{tabular}

\section{Discussion and Conclusion}

In this study, attitudes of Social Studies candidate teachers' regarding contemporary world problems have been examined. The findings of the study show that there is no significant difference between the participants' total scores of attitude towards contemporary world problems and the gender variable. This conclusion is in line with the result Öztaşkın (2014) obtained regarding the gender variable in the relationship between candidate social studies teachers' attitudes towards peace and their attitude towards contemporary world problems. However, in Yazıcı's study (2013) that addresses the attitudes of secondary education students regarding contemporary world problems, it is stated that there is a significant difference between the gender of the research students and their attitude scores regarding contemporary world problems. This result differs from the current research result.

It is seen that there is no significant difference between social studies candidate teacher's attitude regarding contemporary world problems and their undergraduate level. In other words, it can be stated that the undergraduate year of the participants does not cause any difference in their attitudes towards contemporary world problems. This result differs from the result of the study conducted by Avcı and Gümüş (2017) with candidate social studies teachers'. The researcher stated that the attitudes of 
candidate teachers' differ depending on their undergraduate year. In addition, Yazıc1 (2013) concluded that students' attitudes do not show a significant difference depending on the variable of the type of school they continue their education at.

It is seen that there is no significant difference between social studies candidate teachers'total scores obtained from the attitude towards contemporary world problems and the variable of following printed or electronic newspapers daily. In other words, this finding can be interpreted that participants' status of following daily news in printed or electronic forms do not cause them to differentiate from contemporary world problems. In the research of Uymaz (2021), the data on the frequency of following the news regarding contemporary world problems showed that 2 candidate teachers' replied to the question with 1-2 days a month, 10 candidate teachers' replied with 3-4 days a week and 11 candidate teachers' replied with "every day". In addition, it is seen in the research results that participants' replied to the question regarding their source of obtaining information by naming social media applications such as Facebook, Instagram and Twitter and magazines and newspapers. candidate teachers' participating in the study of Şeyihoğlu, Sever and Özmen (2017) perceive educational institutions as the main source of knowledge regarding contemporary world problems. In addition, participants stated that they obtained information regarding contemporary world problems from the news, the internet, television and extracurricular studies, respectively. Libraries, official institutions, posters and notices are stated in the research findings as the least referenced sources for the participants to obtain information about contemporary world problems. In addition, according to the analysis of the relevant scale used by Avcı and Gümüş (2017) to determine whether the participant scores obtained from the sub-dimensions of sensitivity to human problems, sensitivity to environmental problems, participation in the solution and the general average of the relevant scale differ according to the newspaper reading status variable, it has been concluded that the sub-dimensions of sensitivity to environmental problems and participation in the solution differ in favour of those who read newspapers and there is no differentiation in terms of other dimensions and general average. The researcher analyzed to determine whether it would differ significantly according to the variable of the duration of using the 
internet and concluded that there is not a significant difference in sub-dimensions and overall average.

There is no significant difference between the total attitude scores of social studies candidate teachers' and the variable of being a member of NGOs. This finding can be interpreted as the fact that the participants are members of non-governmental organisations does not cause a difference in their attitudes towards contemporary world problems. Uymaz (2021) stated in a research that two participants in the research taking part in the application were members of an organization established to solve problems in the world. In addition, it was stated that a positive feedback was received from 10 participants when asked the additional question "would you like to become a member of an organization that aims to solve problems in the world?". In addition,13 participants in the research did not express any opinion about their desire to become a member of any aid organization that seeks solutions to world problems. It is seen that $10,1 \%$ of the candidate teachers' who participated in Şeyihoğlu, Sever and Özmen's (2017) research participated in the activities of organisations seeking solutions to contemporary world problems, 7,34\% occasionally attended in activities, $27,52 \%$ have never participated and did not wish to participate in them and 55,04\% wished to participate in such organisations' activities. \%55.04'ünün

It is seen that there is a significant difference between the total scores of social studies candidate teachers' attitudes towards contemporary world problems and the mother education level variable. A significant difference was observed between the average scores of the attitude towards the contemporary world problems of those with an illiterate mother and the average scores of the attitude towards the contemporary world problems of those with a mother whose education level is high school or university; the difference is in favour of non-literate participants. This finding can be interpreted as attitudes of those with illiterate mothers towards contemporary world problems are fairly more positive. It is seen that there is no significant difference between social studies candidate teachers' attitude scores regarding contemporary problems and their father's education level, which was another variable. This finding can be interpreted as the levels of the participants' fathers' education did not cause any difference in their attitude towards contemporary world problems. 


\section{References}

Avcl, G. and Gümüş, N. (2017). Examining candidate social studies teachers' attitudes towards contemporary world issues. In O. N. Akfirat, D.F. Staub, and G. Yavaş (Eds.). Current debates in education (p.485-506). London: IJOPEC Publication.

Baylan, E. (2009). Examination of connections among nature believes, culture and environmental problems in theoretical context. Ankara University Journal of Environmental Sciences, 1(2), 67-74.

Bell, D. R. (2004). Creating green citizens? Political liberalism and environmental education. Journal of Philosophy of Education, 38(1), 37-55.

Büyüköztürk, Ş., Kılıç-Çakmak, E., Akgün, Ö. E., Karadeniz, Ş. and Demirel, F. (2010). Bilimsel araştırma yöntemleri [Scientific research methods]. (7. Edition). Ankara: Pegem.

Demirkaya, H. (2016). Günümüz dünya sorunlarına genel bir bakış [An overview of contemporary world problems]. In F. Aydın (Ed.). Günümüz Dünya Sorunları [Contemporary world problems] (p.2-14). Ankara: Pegem.

Harris, I.M. (2004). Peace education theory. Journal of Peace Education, 1(1), 520.

Ivanov, O. B. (2018). Problems and risks of the modern world and the ways of their solution. International Journal Of Engineering and Technology, 7(4.38), 1137-1141.

Jeníček, V. (2008). Global problems of the world-structure, urgency. Agricultural Economics-Czech, 54(2), 63-70.

Kan, A. Ü. (2012). The effects of using individual and group mind mapping on students' academic achievement, retention and affective characteristics in social studies course. Ph. D Thesis. Frrat University, Institute of Education Sciences, Elazig.

Karasar, N. (2010). Bilimsel araştırma yöntemi [Scientific research methods]. Ankara: Nobel.

Kılıçoğlu, G., Karakuş, U. and Öztürk, T. (2012). Validity and reliability study of an attitude scale intended for contemporary world issues. International Periodical for The Languages, Literature and History of Turkish or Turkic, 7(4), 2209-2224. 
Özey, R. (2001). Günümüz dünya sorunları [Contemporary world problems]. İstanbul: Aktif.

Özgen, N. (2012). Günümüz dünya sorunları [Contemporary world problems]. Ankara: Eğiten.

Öztaşkın, Ö.B. (2014). Examination of the relation between attitudes towards peace and world problems. Turkish Journal of Education, 3(3), 25-29.

Robertson R. (1992). Globalisation: Social theory and global culture. London: Sage. Şeyihoğlu, A., Sever, R. and Özmen, F. (2018). The current world problems in the social studies and geography teacher candidates' mind maps. Marmara Geographical Review, 37, 1-15.

Tapan, Ç. (2006). Examination of the peace education programme's effects on the conflict resolution skills of students. Master Thesis. Dokuz Eylul University, Institute of Education Sciences, Izmir.

Uymaz, M. (2021). The investigation of prospective social studies 'teacher's perceptions about the today's world problems. Gazi Journal of Education Sciences (GJES), 7(1), 59-79.

World Economic Forum, (2018). The Global Risk Report 2018. 01.02.2021 Retrieved from http://reports.weforum.org/global-risks-2018/.

Yavaş, H. (2011). The approaches of political parties in Turkey on global environmental problems. Journal of Administrative Sciences, 9(1), 199-214.

Yazıcı, H., and Arıbaş, K. (2011). Günümüz Dünya Sorunları [Contemporary world problems]. Ankara: Pegem.

Yazıcı, Ö. (2013). Secondary school students' attitudes towards contemporary world issues. Turkish Studies, International Periodical for The Languages, Literature and History of Turkish or Turkic, 8(6), 807-823.

\section{Citation Information}

Şimşek, Ü. (2021). Examining the attitudes of candidate social studies teachers' regarding the contemporary world problems. OPUS- International Journal of Society Research, 18(Eğitim Bilimleri Özel Say1s1), 3975-3988. DOI: 10.26466/opus.952872. 